\author{
PAWEe CHYC \\ Uniwersytet w Białymstoku
}

\title{
Tworzenie wspólnego ciała, czyli o przetwarzaniu terenu wśród boliwijskich Moré
}

\begin{abstract}
„Albowiem takie zadanie przed sobą postawiłem: słowem pisanym sprawić, byś usłyszał, byś poczuł, a nade wszystko - zobaczył. Tyle i nic więcej, tyle - gdyż w tym jest wszystko".

Joseph Conrad w grudniu $1897 \mathrm{roku}^{1}$
\end{abstract}

Dierwszy raz w życiu znalazłem się w Ameryce Południowej². To czyste sza1 leństwo, pomyślałem. Miałem spędzić w amazońskiej puszczy najbliższe trzy miesiące, a jeszcze trzy tygodnie wcześniej nie znałem w Boliwii nikogo. Siedziałem w fotelu w domu i patrzyłem na bilet lotniczy do La Paz. Teraz, dzięki mojemu uporowi i życzliwej pomocy tak wielu ludzi, znajdowałem się w samym sercu Amazonii na drewnianej barce płynącej w górę rzeki Mamoré. Rzeki stanowiącej granicę pomiędzy Boliwią i Brazylią. Zmierzałem na swoje pierwsze pozaeuropejskie badania terenowe, żyć wspólnie z potomkami Indian Moré, ostatnim już dziś w Boliwii rdzennym ludem mówiącym językiem z niegdyś licznej rodziny językowej chapacura (Birchall, i in. 2016).

\footnotetext{
${ }^{1}$ Conrad, J. (2015). Serce ciemności. Przekł. J. Dukaj. Kraków: Wydawnictwo Literackie.

2 Tekst powstał na podstawie materiałów zebranych w trakcie realizacji grantu finansowanego przez Narodowe Centrum Nauki - „Tradycja z tubylczego punktu widzenia. Współczesność a przeszłość w dyskursie i praktykach Indian Moré z Amazonii boliwijskiej" (2015/17/N/ HS3 /00078).
} 
Leżałem $\mathrm{w}$ hamaku rozciągniętym $\mathrm{w}$ poprzek barki i topiłem się w upale. Temperatura była tak wysoka, że niemal umożliwiała zobaczenie powietrza. Podobne doświadczenie może nas spotkać w saunie, pomyślałem. Z tą różnicą, że z tej „amazońskiej sauny” nie ma jak szybko się wydostać. Jedyną nadzieję na przetrwanie dawał lekki powiew wiatru wywoływany powolnym ruchem barki w górę rzeki. Mogłem wyczuć, jak ogromne masy brunatnej wody stawiają opór sunącej pod prąd konstrukcji. Czułem ten opór wyraźnie, tak jakby barka była przedłużeniem mojego ciała i moich zmysłów. Dookoła mnie rozpościerały się granice mojego poznania - strzeliste gęste ściany zielonej puszczy. Wiecznie żywy, deszczowy las Amazonii, ten sam, o którym tak wiele czytałem i słyszałem. Teraz on patrzył na mnie.

Na barce razem ze mną podróżowała Indianka Moré o wdzięcznym imieniu Maria wraz ze swoim kilkuletnim synkiem. Maria jest żoną Pastora. Tutaj pierwsza lekcja. O tym, jak słowa potrafią zmylić. Pastor to nie funkcja, to imię. Pastor miał nas odebrać z barki małą łodzią w pobliżu osady Sorpresa, u ujścia rzeki Guaporé. Z miejsca, gdzie mieliśmy dotrzeć po 48 godzinach drogi tą właśnie barką. Wtedy jeszcze tego nie wiedziałem, ale Pastor i Maria mieli stać się w przyszłości moimi przybranymi rodzicami. To oni podczas wielokrotnych potem moich pobytów pośród Moré dbali o moje bezpieczeństwo. Byli moją rodziną, z którą dzieliłem codziennie przestrzeń i posiłki. Ich synowie uczyli mnie łowić piranie i chodzić po lesie. Ich historie poznałem jako pierwsze. Jednak tego dnia na barce Pastor wciąż pozostawał dla mnie zupełnie obcy, a Marię poznałem dosłownie kilka dni wcześniej dzięki niesamowitej pomocy doktora Gilla de Catheu z brazylijskiego Guajará-Mirim.

Kiedy napisałem do znanej brazylijskiej antropolożki Aparecidy Vilaçy, specjalistki od etnografii ludu Wari' (mówiącego również językiem z rodziny chapacura), że chciałbym prowadzić badania terenowe pośród Moré, od razu poleciła, abym skontaktował się z doktorem Gillem. Okazało się, że zna go każdy badacz, który „zapuszczał” się w rejony rzeki Guaporé. Człowiek legenda, francuski misjonarz, lekarz i antropolog. Znawca języków i kultur indiańskich dorzecza Guaporé. Bez jego pomocy nie dotarłbym tak szybko do Moré. To on przedstawił mnie rodzinie Pastora, która przez kilka miesięcy w roku mieszka w boliwijskim Guayaramerín, najbliższym mieście, od którego wioski Moré oddalone są mniej więcej o 54 godziny łodzią w górę rzek³

Podróż na barce przebiegała bez przeszkód, leniwie i bez większych wygód ${ }^{4}$. Łazienkę i toaletę zarazem stanowiła mała łódeczka ciągnięta w tyle barki. Załoga składała się z kapitana, mechanika i kilku pomocników oraz żony kapitana z dziećmi. Kobieta zajmowała się gotowaniem posiłków dla wszystkich. Maria

${ }^{3}$ Łodzią z silnikiem o napędzie od 8-12 KM (tzw. peke peke, powszechny środek transportu wśród lokalnej ludności) potrzeba około 54 godzin, aby pokonać trasę z Guayarmerín do wioski Indian Moré, poruszając się w górę rzek Mamoré i Guaporé, a potem, w zależności od pory roku, albo w górę rzeki Azul, albo poprzez zalaną pampę. Droga powrotna łodzią z silnikiem o tej samej mocy zajmuje już tylko ok. 28 godzin, ponieważ podróż przebiega w dół rzek.

${ }^{4}$ Barki te służą do transportowania rzeką drewna, paliwa i produktów spożywczych. W Amazonii rzeki to drogi. 
i żona kapitana spędzały czas razem. Przez całą podróż. Ja zostałem ulokowany na przodzie barki w towarzystwie jeszcze jednego pasażera, którym okazał się Luis. Student Akademii Sztuk Pięknych z Madrytu, który stracił wenę twórczą i postanowił ją odzyskać, podróżując po Amazonii.

Siedząc na dziobie barki, oddaleni od reszty załogi kontemplowaliśmy naszą wspólną podróż, aż nagle zaskoczyło nas pewne wydarzenie. Wszystko zaczęło się od tego, że Luis zauważył coś w rzece przed nami. Przyglądałem się z uwagą miejscu, które wskazywał i widziałem wyraźnie. W rzece znajdowało się duże zwierzę. Wciąż nie potrafiłem rozpoznać, co to jest. „To chyba tapir!” - powiedziałem wreszcie. Patrzyliśmy obaj zdumieni, jak z jednego brzegu rzeki na drugi przepływał okazały ssak (Tapirus terrestres).

Podczas gdy my delektowaliśmy się tym pięknym widokiem amazońskiego świata, na pokładzie barki poniósł się straszny raban. „Anta! Anta!”. Padła lokalna nazwa tapira w języku hiszpańskim, której jeszcze wtedy nie znałem. „Nie ma broni! Nie ma broni!" - krzyczeli załoganci. Podczas gdy tapir zbliżał się do naszej burty, my gringos z coraz większym zdumieniem wpatrywaliśmy się $\mathrm{w}$ to, co działo się na pokładzie barki. Naszym oczom ukazało się ogromne poruszenie wszystkich poza nami. Niemal każdy wskazywał na tapira i krzyczał: „nie ma broni!" (no hay arma!). Dzieci próbowały rzucać w zwierzaka jakimiś luźnymi elementami znalezionymi na pokładzie. Przez chwilę mieliśmy wrażenie, że kapitan będzie zawracał, ponieważ wykonał dość dziwny manewr, jakby chciał uderzyć $\mathrm{w}$ tapira barką. $Z$ całego tego wrzasku wyłapywałem jedynie pojedyncze zdania: „No zabijcie go! Wiosłem! Wiosłem!" - krzyczał z mostku kapitan.

W czasie tego zamieszania barka zdążyła już minąć tapira i wszyscy pobiegliśmy na jej tył. Tam zobaczyłem, że mechanik razem z dwoma pomocnikami wsiadają do małej łodzi (uczepionej w tyle barki niedaleko „łazienki") i uzbrojeni we wiosła pędzą z nurtem rzeki za biednym tapirem, który wciąż jeszcze miał do pokonania kilkanaście metrów do brzegu. Luis spojrzał na mnie i pyta: „Oni naprawdę mają zamiar zabić go wiosłem?”. „Na to wygląda” - odpowiedziałem równie zaskoczony. Kapitan zmniejszył obroty silnika, a my w zdumieniu patrzyliśmy, jak w oddali dwóch mężczyzn próbuje wiosłami dosięgnąć tapira, który już był prawie na drugim brzegu.

Ku mojej i Luisa radości, a rozpaczy pozostałych członków tej podróży, tapir zdołał uciec. Ta scena już na zawsze zapisała się w mojej pamięci. Oto przed moimi oczami rozegrało się coś, czego byłem współuczestnikiem, a czego nie rozumiałem. $Z$ jednej strony wszyscy widzieliśmy to samo. Tapira przekraczającego rzekę. Jednak każdy z nas widział coś innego. Czułem, że to jest właśnie to, co w antropologii nazywają terenem.

Przodkowie współczesnych Moré mieszkali w rejonie ujścia rzeki Guaporé do rzeki Mamoré na długo zanim powstało państwo boliwijskie i jego granice. Z kronik i opracowań historycznych wiemy, że w misjach jezuickich zakładanych 
nad obiema rzekami podejmowano wiele (zasadniczo nieudanych) prób ich nawrócenia (Meireles 1989). W drugiej połowie XVIII wieku, po opuszczeniu boliwijskiego Mojos ${ }^{5}$ przez Jezuitów, te grupy Indian, które doświadczyły życia w misjach, powróciły do dawnego osadnictwa i swych krewnych na obszarach varzea. Tak w Amazonii nazywa się obszar leśny (a miejscami także sawann) w pobliżu dużych systemów rzecznych zalewany w znacznym stopniu w porze deszczowej przez wody tych rzek. Właśnie po raz pierwszy zmierzałem takim zalanym lasem do największej wioski, w której mieszkają dziś rodziny Moré. W pobliże miejsca, gdzie pod koniec lat 30. XX wieku miał miejsce pierwszy pokojowy kontakt boliwijskiego społeczeństwa z tym ludem.

Zawsze byłem pełen podziwu dla niesamowitej orientacji Moré w terenie i ich znajomości lokalnej przyrody. Z mojego punktu widzenia cała ta podróż wyglądała, jakbyśmy od wielu godzin błądzili po zalanym wodą lesie, jednak nagle, wyłaniamy się z gęstwiny tuż przed samą wioską. Wreszcie widzę ją po raz pierwszy. Wówczas osiągam fizyczny cel mojej podróży. Wioska nosi nazwę Monte Azul (Niebieski Las). Wtedy nie wiedziałem jeszcze, jak wiele razy później będę przemierzał różne drogi do tej osady. Nie wiedziałem o tych wszystkich miejscach, które były w pobliżu. O których Moré tyle mnie potem nauczyli. Pamiętam tamten pierwszy obraz pomimo wielu lat, które minęły. Na nabrzeżu wioski stała tylko jedna osoba: białosiwa staruszka, o imieniu Carmencita. Potem okazało się, że jest jedną z ancianos, czyli najstarszych osób, które pamiętały życie w malokach ${ }^{6}$ w lesie, zanim Moré zostali „oswojeni” (amansados - ujmując to słowem, którego sami najczęściej używają w tym kontekście). Potem okazało się, że była jedną z tych, które najczęściej uciekały ponownie do lasu. Ilekroć umykała, przyprowadzano ją z powrotem. Nie lubiła tego nowego życia, nie lubiła jedzenia z solą, nie lubiła ryżu, nie lubiła mówić po hiszpańsku. Pamiętam jej twarz wtedy na nabrzeżu. Mrużyła oczy i wydawała mi się lekko uśmiechnięta. Przywitałem ją po hiszpańsku. Odpowiedziała po hiszpańsku. Przez wiele lat nie chciała ze mną rozmawiać w swoim rdzennym języku. Twierdziła, że go nie zna, że nigdy nie mówiła, że nie jest „dzikuską” (yo no soy india), jest cywilizowana (soy civilisada). Minęło wiele czasu zanim udało mi się z nią porozmawiać w języku moré. Tego dnia była jedyną osobą, która przyszła na brzeg mnie powitać.

Potem zrozumiałem, że to było bardzo nietypowe. Zazwyczaj wszystkie przyjazdy obcych są znane społeczności z wyprzedzeniem. Ludzie tłumnie wychodzą, kiedy tylko ma przyjechać ktoś „obcy”. Zazwyczaj jest to „swój obcy”,

\footnotetext{
${ }^{5}$ Niziny Mojos (Llanos de Mojos) są regionem w Boliwii wyodrębnionym według kryteriów historycznych, kulturowych i geograficznych. Jezuickie redukcje misyjne na obszarze Mojos formalnie istniały w latach 1682-1767. Do dziś, moim zdaniem, najlepszym krytycznym opracowaniem tego zagadnienia $\mathrm{w}$ literaturze przedmiotu pozostaje praca amerykańskiego historyka Davida Blocka zatytułowana Mission Culture on the Upper Amazon (1994).

${ }^{6}$ Maloka jest tradycyjną konstrukcją chaty pośród tubylczych ludów Amazonii. Istnieją różne rodzaje malok. Dwie najpopularniejsze to konstrukcje budowane na planie okręgu lub prostokąta. W przypadku Indian Moré tradycyjna chata budowana była na planie prostokąta (tzw. longhouse) i została udokumentowana w: Snethlage (1937: 32; 2016: 979) oraz Rydén (1958: 30-31).
} 
bo najczęściej to mniej lub bardziej znani obwoźni handlarze, różnej maści interesanci lub przedstawiciele samorządu ze stolicy prowincji. Ja również kilka dni, a nawet tygodni wcześniej zapowiedziałem swój przyjazd w kontakcie radiowym z liderami społeczności. Ludzie wiedzieli, że przyjadę. Wiedzieli, kiedy przyjadę. Nie wiedzieli tylko, kim jestem. Pytanie o status ontologiczny tego, kogo widzę przed sobą, to podstawowe egzystencjalne pytanie w Amazonii.

"Czy ty aby na pewno nie jesteś misjonarzem?" To było niemal pierwsze zdanie, jakie wypowiedział do mnie Wilmar, jeden z liderów w Monte Azul, kiedy przyszedłem się z nim przywitać pierwszego dnia mojego pobytu w wiosce. Jak się potem okazało, był potomkiem Indianki Moré i jednego z Boliwijczyków, który pomagał "cywilizować” Moré w XX w. „Nie chcemy tutaj żadnych misjonarzy" - dodał.

Właściwie przez cały mój pierwszy pobyt w Monte Azul tym, co najbardziej interesowało ludzi odnośnie do mojej osoby, był powód mojej wizyty. Nigdy nie ukrywałem przed nimi celu mojego przyjazdu, badań oraz zainteresowania ich kulturą i historią, jednak nie chcieli uwierzyć, że mogłem zostawić swoich bliskich i jechać na drugi koniec świata, tylko po to, żeby zobaczyć, jak tam ludzie żyją! Kim trzeba być, żeby coś takiego zrobić! Jak można zostawić tak daleko i na tak długo ukochane bliskie osoby? W końcu po kilku tygodniach dociekań wszyscy zgodnie ustalili, że musiałem przyjechać do nich w poszukiwaniu żony. Był to jedyny powód, który wydawał im się wiarygodny, a zarazem rozsądny. Dopiero wówczas stałem się bardziej obiektem żartów niż podejrzliwości z powodu oczywistej gafy, jaką popełniłem. W Monte Azul nie było kobiet niezamężnych ani nawet nastolatek w odpowiednim wieku. Zatem wszyscy śmiali się, że będę musiał porwać komuś żonę (tak jak kiedyś robili to dawni Moré). Wtedy chyba po raz pierwszy dotarło do mnie, że aby rzeczywiście zrozumieć zagadnienia, które chciałem badać pośród Moré, przede wszystkim muszę poznać ich historię.

\section{$* * *$}

Jechałem tam z myślą, że chcę badać animizm (Chyc 2008). Właściwie, od kiedy pamiętam, zawsze nurtowało mnie jedno podstawowe pytanie: jak świat wygląda z punktu widzenia kogoś innego niż ja? Chyba to właśnie pytanie ostatecznie przywiodło mnie na studia etnologii. Na najprostszym poziomie to pytanie dotyczy relacji z innymi ludźmi, jednak na bardziej egzystencjalnym, zamienia się $\mathrm{w}$ filozoficzny problem. Jak świat widzą stworzenia inne niż ja? Wiele lat pracy etnologów w Amazonii ukazało, że cały animizm w tym regionie jest właściwie wyrafinowaną refleksją wokół tego właśnie pytania (Viveiros de Castro 1992, 1998; Descola 1994; Fausto 2012). Jak wygląda świat chociażby z perspektywy dzikiej świni pekari (Tayassuidae)? Wbrew pozorom nie jest to pytanie czysto filozoficzne. Ma bardzo praktyczny wymiar dla kogoś, kto chciałby świnię pekari upolować (najwyżej ceniona dziczyzna pośród Moré). Całkiem możliwe, że na najbardziej podstawowym poziomie animistyczny światopogląd 
jest rozbudowanym systemem wniosków powstałym w odpowiedzi na ten jeden praktyczny problem.

W przypadku animizmu w Amazonii udzielona na to pytanie odpowiedź brzmi zaskakująco. Dzikie świnie pekari siebie widzą jako ludzi (Viveiros de Castro 1998; Stolze Lima 1999, 2000). Z naszego punktu widzenia wyglądają jak zwierzęta, a zarazem nasz potencjalny pokarm. Jednak one siebie same widzą jako ludzi z własną kulturą: domami, systemem pokrewieństwa, kulturą materialną i sposobem życia przypominającym nasz ludzki. Zatem wszędzie mamy potencjalnie do czynienia ze społecznościami ludzi. Zaiste paradoksalna sytuacja. W Amazonii, gdzie (z naszego punktu widzenia) zagęszczenie ludzi jest jednym z najmniejszych na kilometr kwadratowy na świecie, rdzenni mieszkańcy wszędzie dokoła „widzą” społeczności osób „poprzebierane” w ciała zwierząt. Tak więc w Amazonii zawsze istnieje podstawowy egzystencjalny niepokój, że skoro my siebie widzimy jako ludzi, być może z punktu widzenia innych stworzeń jesteśmy widziani jako zwierzęta, jako ich potencjalny pokarm (Viveiros de Castro 2015). Kto naprawdę jest człowiekiem?

Animizm klasycznie był definiowany jako pierwotna forma wierzeń religijnych przypisująca duszę niemal wszystkiemu, co istnieje (Tylor 1896; por. Descola 2013). Na początku naiwnie pytałem wprost: czy zwierzęta mają duszę? W odpowiedzi najczęściej otrzymywałem wzruszenie ramion i filozoficzne "quien sabe..." (któż to wie). Potem zazwyczaj po prostu przysłuchiwałem się temu, co ludzie spontanicznie mówią. Czasami dopytywałem o szczegóły, wtedy otrzymywałem konkretniejsze odpowiedzi, w rodzaju: niektóre zwierzęta mogą sprawić, że zachorujesz: niektóre mogą porwać małe dzieci albo samotne kobiety. Słuchałem wielu współczesnych opowieści łowieckich o spotkaniach ze zwierzętami (najczęściej jaguarem, dziką świnią pekari lub jeleniowatymi), które spośród innych osobników swego gatunku wyróżniały się wielkością i charakteryzowały się nietypowym zachowaniem (na przykład nie uciekały na widok człowieka).

Wszyscy zgodnie stwierdzali, że był to Imwikuti. Terminem tym Moré nazywali dawniej cielesne byty, i zazwyczaj niewidzialne, które mogą objawiać się w zwierzęcej lub ludzkiej formie, ale są potężniejsze od ludzi. Czasem nazywane są władcami (dueños) lub ojcem/matką (padre/madre) określonych gatunków zwierząt (których postać przyjmują), z którymi są w relacji interpretowanej jako rodzicielska. Byty te opisywane są również jako właściciele wielu dóbr, których Moré nie mieli, a których pożądali. Właściwie wszystkie rośliny uprawne (maniok ${ }^{7}$ kukurydza, platany ${ }^{8}$ ) pochodzą od tych stworzeń. Zwierzęta i ryby, które Moré jedzą, a nawet wiedza o tym, jak leczyć choroby, również pochodzi od nich. Byty te potrafią niemal natychmiast transformować rzeczywistość lub może jedynie czyjś punkt widzenia i sprawiać, że zaczyna się widzieć świat tak, jak jedno z ich dzieci (na przykład dzika świnia pekari), a więc swoich dotychczasowych (ludzkich) krewnych zaczyna się widzieć jako nieludzi. Dlatego spotkanie Imwikuti

\footnotetext{
7 Maniok (Manihot Mill.) to rodzaj krzewów i bylin z rodziny wilczomleczowatych.

8 Gatunek rośliny jednoliściennej należący do rodziny bananowatych (Musaceae).
} 
i wchodzenie w relacje $\mathrm{z}$ nimi jest niebezpieczne, ale jest też konieczne, aby zdobyć dobra, które są potrzebne do budowania ciała i społeczności Moré.

Dziś Moré zgodnie przyznają, że dawniej (kiedy żyli w lesie) było pod tym względem dużo gorzej. Imwikuti były niemal wszęd zie i dużo częściej dochodziło do nietypowych spotkań i transformacji. Rzeczywiście, mity i historie, które opowiadają staruszkowie Moré, są pełne takich przemian rzeczywistości lub punktów widzenia, w których nie wiadomo, kto jest człowiekiem i z kim ma do czynienia (Ferrarezi Junior 1997). To wszystko jednak bardzo się zmieniło. Powiedzieliby dziś niektórzy Moré: „Od kiedy poznaliśmy Jezusa Chrystusa zwierzęta, są już tylko zwierzętami. Jedynie dzięki diabelskim mocom (cosas diabólicas) mogą czasem czynić coś złego lub pokazywać się w ludzkiej formie ${ }^{9}$. Wtedy wiadomo, że mamy do czynienia z «rzeczami pochodzącymi z drugiej strony» (cosas del otro lado)". Słysząc takie wypowiedzi, znów wiedziałem, że jeśli naprawdę chcę badać animizm u Moré, najpierw muszę dobrze poznać ich historię.

Okazało się, że historia Moré jest fascynująca i dość wyjątkowa, jak na warunki amazońskie. Większość tubylczych ludów zamieszkujących na nizinnych tropikalnych obszarach Ameryki Południowej doświadczyła procesu włączania w struktury obywatelskie państw, na których terenach żyli dwoma zasadniczymi sposobami: albo w wyniku działalności prozelitycznej misji chrześcijańskich, albo w wyniku często brutalnych w skutkach kontaktów z baronami kauczukowymi, hodowcami bydła i innymi „przedsiębiorcami”, szukającymi zarobku w ostępach puszczy amazońskiej ${ }^{10}$. W przypadku Moré historia była jednak inna, ponieważ zostali oni scentralizowani nie przez misjonarzy czy patronów, ale przez świeckiego pedagoga, który kierował się ideałami wywodzącymi się z filozofii indygenistycznej ${ }^{11}$. Chciał on uczynić z Moré pełnoprawnych obywateli państwa boliwijskiego, z zachowaniem tych elementów ich rdzennej kultury, które uznawał za warte utrzymania. Zanim jednak ten człowiek przybył, w końcu lat 30. XX w., i na stałe scentralizował rozproszone grupy mówiące językiem moré, miało miejsce jeszcze jedno ważne dla Moré wydarzenie, o którym równie często wspominają.

9 Por. Vilaça 2016.

${ }^{10}$ Owi „przedsiębiorcy” działali często poza prawem, wykorzystując ludność rdzenną do przymusowej pracy przy poszukiwaniu kauczuku, gospodarce rolnej, w późniejszych czasach przy poszukiwaniu złota i ropy naftowej. W tym tekście zbiorczo określam ich mianem „patronów”. W ostatnim latach powstały cenne prace krytycznie i kompleksowo analizujące źródła historyczne, dotyczące relacji ludności rdzennej z patronami na terenie nizinnej Boliwii (Villar, Combès 2012; Guiteras Mombiola 2012; Córdoba, Bossert, Richard 2015).

${ }^{11}$ Indygenizm to ruch filozoficzno-polityczny, który pojawił się w końcu XIX w. w Ameryce Łacińskiej i między innymi dążył do nadania obywatelom indiańskiego pochodzenia równego statusu w społeczeństwie (por. Posern-Zieliński 2005). Indygenizm implikował jednak asymilację kulturową, ponieważ równy status zakładał dostosowanie się ludności tubylczej do standardów kultury dominującej (kreolskiej). Dziękuję dr. Radosławowi Powęska za zwrócenie mojej uwagi na ten aspekt oraz za pozostałe cenne komentarze do roboczej wersji tekstu. 
Warto w tym miejscu nakreślić nieco szerszy historyczny i kulturowy kontekst. Od końca XVIII w., kiedy misje jezuickie nad rzekami Guaporé i Mamoré rozpadły się, ludy mówiące wariantami języka moré powróciły do życia w lesie. Okres ten trwał aż do początku XX w. (w przypadku boliwijskich Moré do końca lat 30. XX w.). W tym czasie lokalne grupy Moré najprawdopodobniej żyły w sposób, który możemy określić jako historycznie typowy dla ludów z rodziny językowej chapacura w ogóle, a być może nawet szerzej, charakterystyczny dla areału kulturowego doliny rzeki Guaporé (por. Meireles 1991). Rekonstruując historię i tradycyjny sposób życia dawnych Moré, zacząłem dostrzegać zaskakujące analogie związane z animizmem, mitami i opowieściami zasłyszanymi od współczesnych Moré, o których już wspominałem.

Trzy cechy najbardziej wyróżniały kulturę rodziny językowej chapacura. Po pierwsze, podstawową jednostkę społeczną stanowiła u nich tzw. rodzina rozszerzona. Jej modelem jest mała grupa ludzi (ojciec, matka, ich niezamężne dzieci i najbliżsi samotni krewni) zamieszkująca tę samą przestrzeń, wspólnie spożywająca posiłki i znajdująca się pod opieką lidera, którym najczęściej jest głowa rodziny ${ }^{12}$ (odnajduję tu analogię do wyobrażenia Imwikuti jako ojca i opiekuna swoich dzieci). Po drugie, w większej skali ludy te dzieliły się na wyodrębnione przestrzennie i posiadające egzonim grupy lokalne i terytorialne (dostrzegam tutaj analogię do wyobrażenia świata jako zamieszkanego przez odrębne grupy ludzi w różnych „przebraniach”). Po trzecie, ważnym aspektem budowania relacji między tymi osobnymi grupami było organizowanie naprzemiennych ceremonii, na których jedna z grup pełniła rolę właściciela ceremonii (dostrzegam tutaj ponownie analogię do postaci Imwikuti właścicieli dóbr, zwierząt, ryb, roślin etc.). Na tych ceremoniach częstowano przybyłych gości alkoholem z manioku ${ }^{13}$, często doprowadzając ich do utraty przytomności (zmiany punktu widzenia, rzeczywistości). Ceremoniom towarzyszyły szeroko rozumiane relacje wymiany, ale były one potencjalnie niebezpieczne, ponieważ mogły wywołać wzajemną przemoc (Von Graeve 1989; Conklin 2001; Vilaça 2010; por. Meireles 1991).

Świat tych odwiedzających się podczas naprzemiennych ceremonii różnych grup Moré stanowił rodzaj cyklicznie oswajanego wewnętrznego kręgu społecznego mniej lub bardziej obcych sobie ludzi, z którymi komunikacja była jednak możliwa, ponieważ wszyscy oni mówili w języku moré, mieli podobne ciała i zwyczaje (moglibyśmy powiedzieć, że wszyscy oni widzieli siebie nawzajem jako posiadających ludzkie ciała).

Opierając się na lokalnym animistycznym światopoglądzie, możemy założyć, że Moré wyobrażali sobie świat na zewnątrz tego kręgu podobnie - jako różne skupiska grup potencjalnych ludzi, którzy jednak coraz bardziej różnili się od

${ }_{12}$ Rozproszone osadnictwo $\mathrm{w}$ malokach zamieszkiwanych przez tzw. rodzinę rozszerzoną (określaną również jako hearth family w nomenklaturze zaproponowanej dla realiów Amazonii; w: Jackson 1983), rzadko większą niż 20 osób z preferencją do rezydencji patrylokalnej (por. Kairski 1999: 19-22).

${ }^{13}$ Rodzaj napoju alkoholowego wyrabianego z bulw korzenia manioku (Manihot) znany pod lokalną nazwą jako chicha (w języku moré: kopa'). 
Moré. Mówili innymi językami, jedli inne pokarmy, posiadali inne rzeczy i zwyczaje, wreszcie mieli inne formy cielesne (na przykład wyglądające jak zwierzęce ciała), chociaż Moré wiedzieli, że te inne byty same siebie mogły widzieć jako posiadające ludzkie ciała. W tym kontekście wiele kosmologicznych mitów i opowieści ancianos nabiera głębokiego socjologicznego sensu.

Rekonstruując historie Moré, zauważyłem, że o ile między swoimi grupami lokalnymi starali się unikać przemocy i zdobywać pożądane dobra na drodze wymiany $^{14}$, o tyle z grupami potencjalnie ludzkimi, z którymi nie uczestniczyli w naprzemiennych ceremoniach (nazwijmy je grupami „na zewnątrz”), utrzymywali drapieżne relacje i starali się pozyskać wszelkie dobra bez zachowania wzajemności. Wymownym tego przykładem były wyprawy wojenne (warfare) ${ }^{15}$, które Moré organizowali (do końca lat 30. XX w.), napadając na barki spływające rzekami Mamoré i Guaporé, a także napadając lub po kryjomu „okradając” osiedlających się w pobliżu ich terenów hodowców bydła (por. Leigue Castedo 1957). Te wrogie stosunki ze społeczeństwem boliwijskim były jedną z bezpośrednich przyczyn projektu „pacyfikacji Moré", podjętego przez rząd boliwijski w 1938 r., pod kierownictwem wspomnianego już świeckiego nauczyciela i patrioty Luisa Leigue Castedo (1957). Zanim jednak do tego doszło, wcześniej miało miejsce interesujące wydarzenie.

W latach 1933-1935 niemiecki etnograf i przyrodnik, Emil Heinrich Snethlage, podczas swojej wyprawy nad rzekę Guaporé był w stanie nawiązać wielomiesięczny pokojowy kontakt z dwiema grupami terytorialnymi Moré, kiedy żyły one jeszcze w lesie, zasadniczo praktykując opisane wyżej wrogie relacje wobec obcych. Kiedy w 2012 r. natrafiłem na jedyną jego publikację, która w postaci popularnonaukowej powieści przybliżała to spotkanie (Snethlage 1937), intuicyjnie czułem, że muszę nawiązać kontakt z jego rodziną. Chciałem poznać lepiej tę historię, chciałem wiedzieć, jak Snethlage to zrobił, że był w stanie nawiązać pokojowy kontakt $\mathrm{z}$ Moré $\mathrm{w}$ czasach, kiedy nie praktykowali oni jeszcze takich relacji z potencjalnymi ludźmi „z zewnątrz". Moje wysiłki zostały nagrodzone i pod koniec 2013 r., w Poczdamie pod Berlinem, udało mi się spotkać z Rotgerem Snethlage, synem niemieckiego etnografa. Dziś postrzegam tę wizytę jako przełomową dla moich badań. Okazało się, że Rotger Snethlage pracował nad redakcją dziennika terenowego swojego ojca ${ }^{16}$. Dziennika opisującego tę właśnie wyprawę nad rzekę Guaporé, w trakcie której między innymi spotkał się on z grupami

\footnotetext{
${ }^{14}$ Na poziomie grup lokalnych dominowała relacja wzajemności. Jednak już na poziomie grup terytorialnych (o rząd wyżej w kategoriach „obcości”) nie zawsze się to udawało i - jak pokazują moje badania etnohistoryczne (w opracowaniu) - różne formy przemocy potencjalnie mogły pojawiać się pomiędzy grupami terytorialnymi Moré. Chodzi tutaj zarówno o przemoc z naszego punktu widzenia fizyczną (bezpośrednie zabijanie), jak również symboliczną (szamanistyczne działania mające na celu uśmiercenie osoby).

15 Wyprawę wojenną należy rozumieć tutaj nie w sensie klasycznym, charakterystycznym dla historii europejskiej, lecz jako techniczny termin warfare. Jest to wyprawa mająca na celu n i e zabicie jak największej liczby wrogów, lecz zdobycie fizycznych lub symbolicznych obiektów służących do reprodukcji fizycznej i społecznej własnej grupy (zob. Kairski, Buliński 2006).

16 Owa "redakcja” obejmowała przepisanie na komputerze notatek terenowych wypełnionych ręcznym pismem, a także sporządzenie obszernych aneksów i przypisów aktualizujących te
} 
Moré i udokumentował ich tradycyjną kulturę (Snethlage 2016). Zanim jeszcze dziennik został opublikowany, Rotger Snethlage życzliwie udostępnił mi w większości do dziś nieopublikowane zdjęcia z lat 1933-1934, abym ich kopie mógł wykorzystać do własnych poszukiwań etnohistorycznych.

Wreszcie, zamiast pytać o abstrakcyjne wydarzenia z przeszłości, mogłem pytać o konkretne osoby, z którymi spotkał się Snethlage, a w wielu przypadkach dysponowałem zdjęciami tych osób. To zupełnie zmieniło charakter moich badań, jak również przyniosło nieoczekiwane rezultaty, ale także nowe dylematy, z których każdy wymagałby niemal osobnego wprowadzenia w tym tekście. Dość powiedzieć, że - ze względów światopoglądowych - oglądanie zdjęć zmarłych było dla Moré doświadczeniem niecodziennym. W trakcie takich sesji niektórzy twierdzili na przykład, że ludzie obecni na tych zdjęciach to nie są ich ojcowie czy dziadkowie, lecz są to inni Moré mieszkający teraz w Namatuke ${ }^{17}$. Kiedy zadawałem więcej szczegółowych pytań, dowiedziałem się, że Namatuke jest miejscem, do którego po śmierci udają się zmarli Moré. Najczęściej opisywane jest ono jako wioska pod powierzchnią wody (ale również jako wioska ukryta za ścianą lasu), która w normalnych warunkach ${ }^{18}$ jest niedostępna (nie można jej zobaczyć ani dostać się do niej). Jednak zdaniem wielu moich rozmówców, Namatuke i jej mieszkańcy istnieją również teraz. Zanim pokazałem im te zdjęcia, Moré nigdy wcześniej nie mówili mi o tym miejscu. Jak widać, jedno pozornie nieszczególne (z naszego punktu widzenia) wydarzenie może wywołać w terenie nowe treści i nowe problemy badawcze.

W tym tekście chciałbym skupić się jednak na innym aspekcie tej historii, który nieustannie pojawiał się, kiedy rozmawiałem z Moré o Snethlage. Dwoje moich rozmówców było małymi dziećmi, kiedy Snethlage próbował nawiązać pokojowy kontakt, a potem odwiedzał chaty Moré, i dzieliło się własnymi wspomnieniami z tych czasów. Inni przywoływali wspomnienia rozmów ich rodziców, którzy opisywali spotkania z etnografem. We wszystkich tych relacjach spontanicznie ze strony Moré pojawiał się zawsze jeden główny motyw. Snethlage był przedstawiany jako dueño (właściciel), który posiadał wiele dóbr, których Moré pożądali i który szczodrze dzielił się z nimi tymi dobrami. Kiedy tylko przestawałem zadawać pytania i słuchałem tego, co Moré sami mówią o tych spotkaniach, nie było rozmówcy, który nie wyliczałby, ile to rzeczy Snethlage posiadał (maczety, noże, guziki, wisiorki etc.) i jak obdarowywał nimi. W opowieściach tych podkreślano również, że Toto ${ }^{19}$ potrafił wymawiać niektóre słowa w języku moré, oraz że spożywał napój kopa', kiedy odwiedzał maloki Moré. Niektórzy sugerowali również, że leczył ich rodziców. Przy czym owo leczenie polegało na odmuchiwaniu tytoniem ciała chorych (na polecenie innych Moré, czyli krewnych tych

notatki ze współczesną wiedzą etnologiczną i lingwistyczną na temat regionu. Ostatecznie dziennik na temat całej wyprawy liczy ponad 1200 stron (Snethlage 2016).

${ }^{17}$ W języku moré nazwa Namatuke dosłownie oznacza miejsce, gdzie są (lub „rodzą się”) brazylijskie orzechy (Bertholletia excelsa).

${ }_{18}$ Przez normalne warunki Moré rozumieją nieprzebywanie samotnie i nieznajdowanie się w trakcie snu.

19 Tym terminem Indianie określali Snethlage w języku moré. 
chorych). To fakt, który Snethlage sam odnotował w swoim dzienniku terenowym (Snethlage 2016: 271-272, 276).

Po jakimś czasie zacząłem postrzegać te opisy jako uderzająco podobne do wizerunku Imwikuti, bytów posiadających dobra, których Moré pożądali oraz z którymi starali się wchodzić w pokojowe relacje, żeby te dobra otrzymać. W opowieściach o Imwikuti również pojawiały się relacje o tym, że niektóre z nich leczyły Moré lub przekazywały im wiedzę, jak leczyć albo też Moré zdrowieli w wyniku samego spotkania z nimi. Jednak ten sam Imwikuti, zamiast leczyć, może spowodować chorobę i przyczynić się do śmierci ${ }^{20}$. Leczenie, ale także potencjalne powodowanie śmierci, to powszechna ambiwalentna cecha charakterystyczna dla szamanów w Amazonii (Fausto 2012). Bardzo często Imwikuti opisywane są również jako szamani (dla swoich grup). Jednocześnie to szamani Moré mogli z Imwikuti utrzymywać regularne i owocne relacje bez ryzyka zachorowania czy trwałej zmiany punktu widzenia na swoją codzienną rzeczywistość.

Zaczynałem od zgłębiania historii Moré, żeby lepiej zrozumieć animizm. Tymczasem okazało się, że nie tylko dzięki poznaniu historii Moré ich animistyczny światopogląd staje się dla mnie bardziej czytelny, ale również działa tutaj interesujące sprzężenie zwrotne. Animizm zdaje się również przenikać sposób, w jaki Moré opowiadają historię i to, na co sami zwracają uwagę, gdy mówią o przeszłości.

$\mathrm{Z}$ czasem podobne analogie odnalazłem $\mathrm{w}$ opowieściach na temat wspólnego życia z Luisem Leigue Castedo, który razem z małżonką Yolandą Suarez Castedo żył pośród Moré od roku 1939 niemal nieprzerwanie do roku 1962. Znów, kiedy tylko przestałem skupiać się na moich pytaniach i przysłuchiwałem się temu, jak Moré mówią o czasach Leigue (el tiempo de los Leigue), na pierwszy plan wysuwały się elementy, które z naszego punktu widzenia mogą się wydawać mało istotne. Większość moich rozmówców przede wszystkim podkreślała ilość jedzenia i rzeczy, których była obfitość (harto) w czasach Leigue. Podkreślali oni, jak uczyli się spożywać posiłki z solą, jak trudno było im przyzwyczaić się do jedzenia, którego wcześniej nie znali (ryż, cukier, kawa, herbata, etc), jak trudno było przyzwyczaić się do nowego sposobu spożywania posiłków (jedzenia z dala od krewnych, rozsadzonych w jadłodajni z podziałem na płeć i wiek). Niemal zawsze następowało wyliczanie, jakiego typu jedzenie było dostępne i jak wiele go było. Jak wiele rzeczy Leigue rozdawał (narzędzia, odzież, nasiona, owoce itp.). Ponownie nasuwająca się tutaj analogia do postaci ojca (lidera), dbającego o swoje dzieci, w tym przypadku jest dodatkowo wzmocniona faktem, że Moré rzeczywiście zwracali się do małżeństwa Leigue terminami pokrewieństwa, oznaczającymi ojcze (ite') i matko (ina'); (por. Leigue 1957).

Oczywiście spotkać można było różne opinie na temat czasów Leigue, zależne od osobistych doświadczeń. Niektórzy podkreślali pozytywne aspekty, jak wspomniana już obfitość, ale również poczucie bezpieczeństwa, opieka nad

\footnotetext{
${ }^{20}$ W tym kontekście również znamienny jest fakt, że grupy Moré, w latach 1933-1938, kiedy intensywność ich pokojowych kontaktów z obcymi była najwyższa, doświadczały również najsilniejszych fal chorób zakaźnych (grypa, żółtaczka, odra).
} 
chorymi. Inni byli wdzięczni za to, że poznali Jezusa Chrystusa, nauczyli się hiszpańskiego, a nawet, że nauczyli się pracować (aprendimos trabajar). Jeszcze inni mieli za złe, że byli dyscyplinowani (również poprzez kary cielesne), rozłączeni od swoich dzieci oraz od bliskich krewnych. Wypominali, że musieli pracować i przebywać długo w otoczeniu obcych (karafo) ${ }^{21}$.

Historia Moré w czasach Leigue jest złożona i niejednoznaczna, a niemal każdy z tych wątków wymaga osobnego wprowadzenia w kontekst wydarzeń. Jednak chcę zwrócić tutaj szczególną uwagę na to, co w pewnym momencie dla mnie również stało się najważniejsze, mianowicie na sposób, w jaki Moré mówią o tej przeszłości oraz na co oni sami zwracają uwagę lub kładą nacisk, kiedy opowiadają o czasach Leigue. Mógłbym skupić się na wątkach, które nam antropologom wydają się ważne, takich jak kolonialny wręcz charakter relacji między Leigue (czy szerzej Boliwijczykami) a Moré, czy też rozważać etyczne problemy związane z ich przeszłością, wykazywać asymetryczność tych relacji lub opisać reżim władzy, jaki się z nich wyłania (por. Guiteras Mombiola 2019). Jednak są to narzędzia teoretyczne i są to problemy, które pochodzą z naszego akademickiego świata. W pewnym momencie bardziej zaczęło mnie interesować, jakich pojęć sami Moré używają do myślenia o tej przeszłości. Chciałem zrozumieć, dlaczego, kiedy stawiam otwarte pytania o przeszłość lub słucham spontanicznych wypowiedzi tych ludzi, otrzymuję od nich historie, które skupione są na zaskakujących dla mnie kwestiach, na które ja sam nie zwróciłbym większej uwagi.

Dlaczego na pierwszy plan tych opowieści wyłaniają się wątki związane z pożywieniem? Dlaczego najtrudniejsze wspomnienia dotyczyły rozłąki z bliskimi, zakazu mówienia w języku moré, kar cielesnych, trudności z akceptacją dyscypliny w szkole czy w pracy, trudności z zaakceptowaniem soli i innych produktów nieznanych wcześniej dla Moré? Dlaczego zasadniczo większość z tych narracji dotyczy trudności wspólnego życia w jednej wiosce z obcymi? Im więcej słuchałem tych opowieści, tym bardziej miałem wrażenie, że te początkowo niezrozumiałe dla mnie kwestie mają mi coś bardzo ważnego do powiedzenia na temat historii Moré, ale również na temat ich współczesności. Kiedy zacząłem przyglądać się im w poszukiwaniu spajających te opowieści elementów, zdałem sobie sprawę, że wszystkie one orbitują wokół pojęcia ciała. Tyle że rozumianego w specyficzny dla Moré sposób.

W języku moré termin, który można przetłumaczyć jako (ludzkie) ciało to słowo it. Co ciekawe, jest to źródłosłów pojęć ite' oraz iten. Pierwsze można przetłumaczyć jako „ojciec”, natomiast drugie jako „człowiek” (ktoś, kto z punktu widzenia Moré ma w pełni ludzkie ciało). Iten oznacza również po prostu „ludzie"

${ }^{21}$ Właściwie przez cały okres czasów Leigue Moré żyli w otoczeniu wielu nieindiańskich Boliwijczyków (karafo). Na początku byli to przydzieleni przez boliwijski rząd żołnierze i robotnicy, którzy pomagali budować tzw. Nucleo Indígenal Moré (ośrodek tubylczy Moré). Leigue zatrudniał potem również wielu nauczycieli i pomocników przy hodowli bydła oraz poszukiwaniu kauczuku, z którymi Moré pracowali. Więcej tych historycznych kontekstów przybliżam w odrębnym tekście (Chyc 2017). 
i prawdopodobnie był to etnonim o najszerszym generycznym znaczeniu dla wszystkich ludów mówiących wariantami języka moré2 ${ }^{2}$. Innymi słowy, zbiorczym terminem „ludzie” (iten) różne grupy Moré określały wszystkie pozostałe, z którymi (z ich punktu widzenia) komunikacja była możliwa w języku moré $i$ które miały takie same lub bardzo podobne zwyczaje żywieniowe oraz podobną kulturę materialną (rodzaj strzał, narzędzi, strojów, malunków na ciele i innych form „ozdabiania" ciała), czyli wszystko to, co składało się na zewnętrzną wizualną postać („,przebranie”), pod jaką dana osoba jest widoczna dla innych.

Dopiero wychodząc od kategorii pojęciowych „zaproponowanych" przez samych Moré, można spostrzec, że nagle wszystko zaczyna się układać w zaskakująco spójną całość. Kiedy wrócimy do wspomnianych przeze mnie wcześniej trzech głównych wyznaczników tradycyjnej kultury ludów z rodziny językowej chapacura, zobaczymy, że na pierwszym miejscu znajduje się właśnie pojęcie ciała. It (ciało) stanowi źródłosłów pojęciowy terminu ojciec (ite'), a zarazem podstawową kategorię społeczną dla ludów z rodziny językowej chapacura, jaką jest rodzina rozszerzona, znajdująca się pod opieką lidera. Ujmując rzecz najprościej, współdzielenie przestrzeni i czasu oraz wspólne spożywanie posiłków (konsumowanie tych samych substancji, często z tego samego naczynia) dosłownie jest procesem budowania wspólnego ciała (lub jeśli ktoś woli, wspólnoty bardzo podobnych ciał). Chodzi tutaj o to, żeby bliscy krewni mieli ciała (rozumiane szeroko, również jako zwyczaje i sposób życia, który te ciała umożliwiają) jak najbardziej podobne do siebie, po to żeby widzieli siebie nawzajem jako ludzi (iten). Innymi słowy ciało jest źródłem punktu patrzenia na świat (por. Viveiros de Castro 1998). Dlatego jest tym, co trzeba wspólnie budować, i o co trzeba dbać, aby pozostawało podobne. To gwarantuje podobne postrzeganie świata.

Kiedy przyjmie się takie specyficzne rozumienie pojęcia ciała (które występuje w Amazonii nie tylko u ludów z rodziny językowej chapacura, por. Seeger i in. 2019[1979], Viveiros de Castro 1998, 2012), wówczas wiele elementów z historii Moré, i ze sposobu, w jaki mówią oni o przeszłości, okazuje się znacznie bardziej zrozumiałych. Nagle staje się czytelne, dlaczego tak bardzo zwracają oni uwagę na rodzaj spożywanego posiłku (ten sam posiłek czyni ciała podobne do siebie) i nowe nieznane im wcześniej produkty, jak sól, ryż, cukier (nowe substancje zmieniają ciało). Otwierają się nowe możliwości interpretacji rodzajów ich relacji z obcymi oraz wyjaśnienia, dlaczego względem relacji wzajemności akcentują oni podobieństwa. Jak w przy padku spotkań ze Snethlage, kiedy podkreślali, że etnograf spożywał kopa' (współdzielił substancje), i że znał słowa w moré (możliwość komunikacji oznacza potencjalnie ludzką osobę), a także leczył zgodnie $\mathrm{z}$ oczekiwaniami. Leczenie polegało na odmuchiwaniu tytoniem ciała, zatem

${ }^{22}$ Najsilniejszą przesłanką ku temu jest fakt, że pod nazwą Itene ludy mówiące w moré znane są z kronik historycznych z czasów misji jezuickich. W etnologii kultur amazońskich znany jest również fakt, że bardzo często nazwy własne oznaczały po prostu termin „ludzie”. Innymi słowy na pytanie: „kim wy jesteście?”, odpowiadają „jesteśmy iten” (,jesteśmy ludźmi” dokładnie: tymi, którzy widzą siebie jako ludzi). Warto dodać, że termin iten oznacza „ludzi” w obu znanych dziś dialektach języka moré (moré właściwy i kuyubim). 
było dokładnie tym rodzajem leczenia, które praktykowali szamani Moré (podobieństwo praktyk).

Jeśli dostrzeże się wagę, jaką dla Moré ma tworzenie wspólnego ciała poprzez przebywanie razem $\mathrm{w}$ gronie bliskich sobie osób, wspólne spożywanie z nimi posiłków, sposób opowiadania o czasach Leigue również nabiera głębokiego sensu. Staje się czytelne, dlaczego ingerencja w kwestie związane z tak rozumianą cielesnością była najtrudniejszym doświadczeniem dla Moré. Z drugiej strony widać również, dlaczego inne aspekty, w których Leigue spełniał swoją (wyznaczoną przez kulturę Moré) rolę jako ojca (ite'), zapamiętane zostały jako dobre wspomnienia. Jednym słowem, Moré cały czas mówili mi głównie rzeczy, które rzeczywiście dla nich są ważne. Tyle że na początku dla mnie wydawały się one mało istotne i poboczne.

Dokładnie pamiętam ten moment, kiedy uświadomiłem sobie, że dla współczesnych Moré pojęcie ciała wciąż jest pojęciem centralnym i chyba nie do końca rozumieją je oni tak jak ja, chociaż dziś wszyscy w naszych rozmowach używamy hiszpańskiego terminu cuerpo (ciało). Przypomina to trochę scenę z tapirem w wodzie, od której rozpoczęliśmy tę podróż. Niby wszyscy widzą (mówią) to samo, ale tak naprawdę każdy widzi (i mówi) coś nieco innego.

Tego wieczoru, jak zawsze, jedliśmy wspólnie przy jednym stole kolację w domu Alberto ${ }^{23}$ w Monte Azul. Był to jeden z tych trudnych okresów, kiedy nie było dużo jedzenia (czyli ryb lub mięsa, które Moré uważają za właściwe jedzenie), więc na kolację spożywaliśmy smażone „racuchy” (fritos), jak je nazywałem po polsku na własny użytek. Główny myśliwy w naszym domu, Felipe, był chory już od niemal dwóch tygodni i dzięki temu, że wszystko działo się w rodzinie, z którą wtedy mieszkałem, miałem wreszcie okazję posłuchać, bez zadawania (abstrakcyjnych) pytań, co spontanicznie Moré mówią na ten temat. Po raz kolejny opowiadano przy stole, jak trzy tygodnie wcześniej, kiedy Felipe był u swojej teściowej w odwiedzinach z żoną, jej krewni próbowali go zabić. Chodzi tutaj o próbę zabicia za pomocą szamańskich praktyk (hechizo), a dokładnie, z użyciem „rzeczy pochodzących z drugiej strony” (cosas del otro lado). Siostra teściowej Felipe twierdząc, że ktoś inny próbuje rzucić na niego urok, sama chciała to właśnie jemu uczynić. Felipe wielokrotnie podkreślał, jak dotykała jego ciała, jak masowała mu klatkę i stukała w nią pięścią, by po chwili pokazać jemu i wszystkim zebranym, że wyciągnęła z jego ciała kolec płaszczki² ${ }^{24}$ Trzymała go w otwartej dłoni, żeby wszyscy mogli zobaczyć. W tej samej dłoni, którą przed

\footnotetext{
${ }^{23}$ Ze względu na wrażliwość informacji zawartych w tym akapicie imiona bohaterów zostały zmienione.

${ }^{24}$ Płaszczka słodkowodna (Potamotrygonidae) występująca w rzekach Amazonii. W lokalnym hiszpańskim nazywana raya. Posiada ogon z charakterystycznym kolcem jadowym, który w przypadku ukłucia może stanowić dla człowieka śmiertelne zagrożenie.
} 
chwilą masowała mu klatkę piersiową. Wniosek był prosty, kolec musiał być wcześniej w jego ciele.

Tego wieczoru, kiedy siadaliśmy do kolacji, znów mogłem usłyszeć kolejną zbliżoną wersję tej historii. Felipe był leczony w wiosce, ale jego stan się nie polepszał, więc wszyscy twierdzili, że powinien jechać do miasta, ponieważ tam są potężniejsi szamani (brujos). On sam jednak wydawał się nie do końca przekonany, czy jego choroba to urok (hechizo) i twierdził, że powinien iść po prostu do zwykłego lekarza. Od tygodnia debatowano na ten temat. To, co nastąpiło w trakcie kolacji, rozwiało wszelkie wątpliwości.

Pamiętam, że byłem naprawdę głodny i czekałem jak nigdy na te racuchy. Od dłuższego czasu nie mieliśmy już benzyny (do generatora prądu), więc po zapadnięciu zmroku jedliśmy przy świecach. Lubiłem to nawet, ponieważ brak intensywnego światła elektrycznego sprawiał, że człowiek skupiał się bardziej na smaku i zapachu, które stawały się lepiej wyczuwalne. Poza tym było dużo mniej insektów, które zwykle zlatywały się, zwabione intensywnym światłem. Jedyną wadą tej sytuacji pozostawał fakt, że nie było dokładnie widać, co człowiek wkłada do ust. Jedliśmy ze wspólnej miski z racuchami, więc złapałem dwa dla siebie i pierwszego zjadłem niemal na raz. Kiedy ugryzłem drugiego, poczułem jakby metaliczny smak na języku i z zaskoczeniem wyczułem, że moje zęby przegryzają coś bardzo twardego. Na szczęście nie przełknąłem niczego.

Kiedy zbliżyłem zawartość do światła świeczki, ze zdumieniem stwierdziłem, że w moim racuchu znajdowała się ponad czterocentymetrowa igła do szycia, którą przegryzłem na pół! Na szczęście wyplułem obie połowy. Zdiagnozowałem język, nie czułem żadnej rany. Jakimś dziwnym trafem zupełnie nie zostałem nawet zadraśnięty. Nigdy nie zapomnę tego wieczoru i tej kolacji. Dość powiedzieć, że do najbliższego miasta (i szpitala) podróż zajmowała 28 godzin drogi łodzią. W pierwszym momencie wszyscy byli w szoku (przy czym ja zdecydowanie najdłużej). Jak to możliwe, że w racuchach znalazła się igła do szycia ${ }^{25}$ ? Kiedy chwilę później matka Felipe znalazła drugą igłę w swoim racuchu, wszyscy przyznali zgodnie, że to już nie może być przypadek. Ewidentnie to była robota (trabajo) jakiegoś brujo (szamana) ${ }^{26}$. Było oczywiste, że Felipe musi jechać do miasta, żeby udać się do potężnych szamanów nie-Moré, dopiero oni będą mogli go uleczyć. Mnie natomiast polecono udać się do sąsiada, o którym nie wiedziałem nawet, że jest szamanem. Tak oto, dopiero kiedy sam przez chwilę znalazłem się

${ }^{25}$ Warto dodać, że mieliśmy odmienne "teorie" na temat pojawienia się tej igły w racuchach. Ja przypuszczałem, że dzieci mogły włożyć igłę do mąki i jakoś się ona „uchowała” podczas przygotowywania posiłku. Większość zebranych jednak niechętnie ferowała wyroki, a nieliczni skromnie zauważyli, że to mogło być czyjeś intencjonalne działanie, przy czym używali terminu ",hechizo", który oznacza szkodliwe intencjonalne działanie szamańskie.

${ }^{26}$ Brujo jest terminem w lokalnym hiszpańskim oznaczającym szamana (w moré ikat). Przy czym osoba szamana w Amazonii jest inna niż w klasycznie rozumianym szamanizmie syberyjskim. Szaman amazoński jest postacią ambiwalentną (por. Fausto 2012). Równie dobrze może leczyć, jak i rzucać uroki (hechizo). Bardzo często Moré, aby opisać to, co robi szaman, używają hiszpańskiego terminu "pracować” (trabajar), co jest kolejnym przykładem tego, że choć dziś używają słów hiszpańskich, rozumieją je specyficznie. 
w pozycji potencjalnie wystawionego na działanie szamańskie (hechizo), nieoczekiwanie dowiedziałem się, że jednak Moré mają kogoś, kto wie (sabe) ${ }^{27}$. Szamana, który jednak zapytany wprost, sam niechętnie by przyznał, że jest szamanem.

Pouczające jest to, że kiedy wcześniej wielokrotnie pytałem w wywiadach, czy są jeszcze szamani pośród Moré, wszyscy zgodnie odpowiadali, że nie. „Szamanów już dawno tutaj nie ma". Uzasadniając, jedni twierdzili, że są już nowocześni (ya somos moderno), inni, że są wierzący (somos creyentes) i odkąd poznali Jezusa Chrystusa w żadnych szamanów nie wierzą, bo to są rzeczy diabelskie (cosas diabólicas). Wszyscy oni jednak odsyłali mnie do tego samego człowieka, kiedy dowiedzieli się o tym, co mi się przytrafiło. Staruszek spojrzał na mój język, dotykał trochę mojej głowy i twarzy, po czym powiedział: „Twoje ciało jest dobrze zamknięte, to nie było (przeznaczone) dla ciebie" (tu cuerpo está bien cerrado, no era para $\mathrm{t}$ ). Na wszelki wypadek jednak odmuchał mnie jeszcze dymem z tytoniu, tak jak robili to dawni szamani.

Chciałbym zakończyć ten esej kilkoma spostrzeżeniami, które wydają mi się istotne. Przede wszystkim największego przełomu w moich badaniach dokonałem, kiedy przestałem się upierać na pytaniach i wyobrażeniach, z którymi przyjechałem $w$ teren. Nie chodzi tutaj o zrezygnowanie $z$ badania interesującego mnie problemu w ogóle (chociaż czasem teren weryfikuje również samą sensowność problemu badawczego), ale przede wszystkim o sposób jego konceptualizacji i realizacji. Zadawanie przygotowanych wcześniej abstrakcyjnych pytań o animizm przynosiło w efekcie kiepskiej jakości materiał deklaratywny, z którego najczęściej wynikało, że Moré w ogóle niechętnie mówią "o tych sprawach", a już szczególnie w sytuacji, kiedy jest ona wywołana sztucznie. Dużo bardziej owocne okazało się uczestniczenie w sytuacjach, które spontanicznie wywoływały komentarze, takich jak: łowienie i (dużo rzadziej w moim przypadku) polowanie, chodzenie po lesie, oporządzanie upolowanej zwierzyny, praca na poletku. Chodzi o doświadczanie tych sytuacji, obserwowanie i zapamiętywanie, chociażby tych działań Innych, które wydają się nam „dziwne”. Także o podążanie za swobodną rozmową, jeśli taka towarzyszy tym sytuacjom. Raczej o uważne słuchanie tego, co Inni mówią, niż zadawanie im własnych pytań. Innymi słowy, moja wiedza terenowa (i zdolność nadawania jej sensu) wzrastała proporcjonalnie do ilości różnorodnych doświadczeń, $\mathrm{w}$ jakich uczestniczyłem w relacjach z Moré (por. Buliński, Kairski 2011: 291-333).

27 Wiele praktyk i charakterystyk szamanów u Moré (i szerzej w Amazonii) określanych jest potocznymi słowami, które na pierwszy rzut oka w żaden sposób nie implikują praktyk szamańskich. Brujos określani są na przykład jako ci, którzy: wiedzą (saber), widzą (ver/mirar), komunikują się (hablar), pracują (trabajar), dotykają/stykają się (tocar), dmuchają (soplar). Rozpoznanie tych pojęć, jako odnoszących się do szamanizmu, w drodze wywiadu kwestionariuszowego jest dość trudne. 
Jednak oprócz tak rozumianego zbierania przeżyć w terenie, równie cennym źródłem poszukiwania sensu okazała się wiedza zawarta w narracjach na temat przeszłości, a także w opowieściach starców (tzw. cuentos). Na tym etapie przełomem w moich badaniach był moment, w którym znów, zamiast zadawać abstrakcyjne pytania o przeszłość, dzięki wcześniejszej pracy archiwalnej mogłem zdobyć historyczny kontekst oraz przede wszystkim szczegółowe materiały historyczne dotyczące konkretnych osób i sytuacji, wywołujące konkretne wspomnienia. Wspomnienia określonych rozmówców dotyczące ich życia, ale również życia innych osób i sytuacji, których owi rozmówcy nie doświadczyli osobiście. Moment, w którym usłyszałem te wspomnienia ${ }^{28}$, staje się dla mnie kolejnym doświadczeniem kontaktu z Innym. Z mojego punktu widzenia jest to kontakt $\mathrm{z}$ sensem (zakodowanym $\mathrm{w}$ formie narracji), jaki ta osoba (często nieświadomie) nadaje swoim przeżyciom, jak również opowiadanym historiom. Sens ten nie jest łatwo dostępny, ale jest częściowo możliwy do zrekonstruowania. Poprzez analizę sposobu mówienia, jak również (często nieświadomego) doboru kategorii pojęciowych i związków przyczynowo-skutkowych, za pomocą których ta opowieść jest konstruowana (Quinn 2005). Zatem nie tylko praktyka, która niesie wiedzę, ale również narracje, które także są źródłem wiedzy, stają się częścią mojego doświadczenia, zapisanego z kolei w moich wspomnieniach. Jest to równieżjeden $\mathrm{z}$ wymiarów tego, $\mathrm{w}$ jaki sposób teren zaczyna być przetwarzany w moim ciele.

Kolejnym przełomowym dla mnie momentem było potraktowanie tych opowieści (a zatem również osób, które je mówiły) symetrycznie jako równouprawnionych (wobec mojej wiedzy i mojego punktu widzenia) sposobów nadawania sensu światu (Buliński 2019, por. Viveiros de Castro 2004, 2011). W praktyce badawczej polega to na poszukiwaniu kluczowych kategorii pojęciowych, na bazie których narracje Moré o przeszłości są zbudowane i na próbach wyobrażenia sobie sensownego świata opisanego wokół tych pojęć. W przypadku Moré tymi kluczowymi kategoriami, w obecnym stanie mojego rozumienia ich narracji na temat przeszłości, były i są pojęcia, takie jak chociażby: ciało/granica (it), ojciec/ opiekun (ite'), człowiek/ludzie (iten), wróg/obcy (yimuwan/karafo) transformacja/choroba/śmierć (imwi), druga strona (nipakasi) przekraczanie/penetrowanie (korom). Już z tej zwężonej listy wynika, że są to pojęcia inne niż te, wokół których początkowo budowałem swoje rozumienie świata Moré i ich przeszłości, i które oparte były na uprzednich lekturach tekstów i moich pierwszych doświadczeniach $\mathrm{w}$ terenie. Po zidentyfikowaniu kluczowych kategorii pojęciowych dla narracji Moré o przeszłości mogę zacząć budować sieć lokalnych znaczeń i sensów nadawanych przez nich tym pojęciom. Poddając je takiej obróbce, czynię $\mathrm{z}$ nich teoretyczne narzędzia, za pomocą których sam mogę patrzeć na wybrane

${ }^{28}$ Moment usłyszenia staje się również momentem zapisania tego przeżycia w naszych wspomnieniach. Z mojego osobistego doświadczenia wynika, że warto jednak w miarę możliwości dokumentować takie opowieści w postaci nagrań. Nie chodzi tutaj o wywiady, lecz swobodne rozmowy, w których podążamy za tokiem wypowiedzi naszego rozmówcy. Każde ponowne odsłuchanie takiej rozmowy pozwala na nowo odczytywać sensy z tego samego materiału źródłowego, jakim jest nagranie (por. Buliński 2018: 272-281, 2019). 
zagadnienie, które badam (w tym wypadku narracje o przeszłości). Innymi słowy, staram się zbudować sens narracji Moré o przeszłości wyrażony za pomocą pojęć dostarczonych przez nich samych. Zatem na poziomie refleksji metodologicznej i teoretycznej moje wysiłki można umieścić w obrębie tzw. zwrotu ontologicznego (Holbraad, Pedersen 2017).

Warto zauważyć, że postulowana przez zwrot ontologiczny symetryczność wiedzy i sposobu konceptualizowania świata przez antropologa i jego Innego nie jest motywowana zadośćuczynieniem. Bardziej niż kwestiami politycznymi jest ona motywowana uznaniem wspólnego dla wszystkich podmiotów podstawowego problemu poznania (Viveiros de Castro 2004). Zarówno antropolog, jak i jego Inny, są równymi sobie ludźmi, którzy stają przed tym samym dylematem poznania oraz zrozumienia świata i siebie nawzajem. Ich wysiłek w kierunku nadawania sensu działaniom drugiego jest symetryczny (por. Buliński 2019). Dziś widzę jasno, że moje rozumienie procesu nadawania sensu światu Moré, który postrzegam jako intelektualny proces przetwarzania terenu, jest równoprawny z ideą tworzenia wspólnego ciała, wynikającą z konceptualizacji świata za pomocą kategorii pojęciowych bliższych Moré. O ile z mojego punktu widzenia proces poznawania ich świata przebiegał za pomocą głównie intelektualnego przetwarzania informacji (w postaci, tekstu, narracji, przeżyć $\mathrm{i}$ ich wspomnień), o tyle $\mathrm{z}$ ich punktu widzenia, ten sam proces poznawania świata (widzenia go właściwie) może być rezultatem jedzenia tych samych posiłków, fizycznego dzielenia czasoprzestrzeni oraz natężenia i powtarzalności tych relacji. Innymi słowy, porozumienie, które dla mnie jest efektem głównie budowania wspólnoty myśli, dla nich może być efektem budowania wspólnego ciała. Każda z tych dróg ostatecznie umożliwia podobny punkt widzenia. Żadna z tych wizji nie jest gorsza. Obie są racjonalne i obie są prawdziwe.

\section{Literatura}

Birchall, J., Dunn, M., Greenhill, S.J. (2016). A combined comparative and phylogenetic analysis of the Chapacuran language family. International Journal of American Linguistics, 82(3), 255-284.

Block, D. (1994). Mission Culture on the Upper Amazon: Native Tradition, Jesuit Enterprise and Secular Policy in Moxos, 1660-1880. Lincoln: University of Nebraska Press.

Buliński, T., Kairski, M. (2006). Sny, trofea, geny i zmarli: „wojna” w spotecznościach przedpaństwowych na przykładzie Amazonii : przeglad koncepcji antropologicznych. Poznań: Wydawnictwo Naukowe UAM.

Buliński, T., Kairski, M. (2011). Wiedza terenowa w antropologii. W poszukiwaniu nowego wymiaru badań terenowych. W: T. Buliński, M. Kairski (red.), Teren w antropologii. Praktyka badawcza we współczesnej antropologii kulturowej (s. 291-333). Poznań: Wydawnictwo Naukowe UAM.

Buliński, T. (2019). Informator, rozmówca, wspólnik. Obrazy relacji Antropologa z Innym. Prace Etnograficzne, 47(1), 1-16. 
Chyc, P. (2008). Początek religii? Koncepcja animizmu w perspektywie antropologicznej. W: Stawiarski B. (red.), Człowiek, Społeczeństwo, Wiara. Studia interdyscyplinarne (s. 115-128). Wrocław: Wydawnictwo Uniwersytetu Wrocławskiego.

Chyc, P. (2017). Język i małżeństwo. Różnice kulturowe pośród Indian Wari' i Moré z perspektywy antropologii historycznej. Etnografia. Praktyki, Teorie, Doświadczenia (3), 191-210.

Córdoba, L., Bossert, F., Richard, N. (2015). Capitalismo en las selvas. Enclaves industriales en el Chaco y Amazonía indígena (1850-1950). San Pedro de Atacama: Ediciones del Desierto.

Conklin, B.A. (2001). Consuming grief: compassionate cannibalism in an Amazonian society. Austin: University of Texas Press.

Descola, P. (1996). In the Society of Nature: A Native Ecology in Amazonia. Cambridge: Cambridge University Press.

Descola, P. (2013). Beyond Nature and Culture. Chicago: University of Chicago Press.

Fausto, C. (2012). Warfare and shamanism in Amazonia. Cambridge-New York: Cambridge University Press.

Ferrarezi Junior, C.F. (1997). Nas aguas dos Itenes: um estudo semantico com a lingua moré (Dissertação de Mestrado).

źródło: http://www.bibliotecadigital.unicamp.br/document/?code=vtls000115456; [dostęp: 20.05.2014,[

Graeve, B. von. (1989). The Pacaa Nova: clash of cultures on the Brazilian frontier. Toronto: University of Toronto Press.

Guiteras Mombiola, A. (2012). De los llanos de mojos a las cachuelas del beni 1842-1938. conflictos locales, recursos naturales y participación indígena en la amazonia boliviana. Fuentes, Revista de la Biblioteca y Archivo Histórico de la Asamblea Legislativa Plurinacional, 77.

Guiteras Mombiola, A. (2019). School Centres for 'Savages': In Pursuit of a Convivial Sociability in the Bolivian Amazon, Mecila Working Paper Series, 16, São Paulo: The Maria Sibylla Merian International Centre for Advanced Studies in the Humanities and Social Sciences Conviviality-Inequality in Latin America.

Holbraad, M., Pedersen, M.A. (2017). The ontological turn: an anthropological exposition. Cambridge: Cambridge University Press.

Jackson, J.E. (1983). The fish people: Linguistic exogamy and Tukanoan identity in Northwest Amazonia (No. 39). Cambridge: Cambridge University Press.

Kairski, M. (1999). Indianie Ameryki Środkowej i Potudniowej: demografia, rozmieszczenie, sytuacja etno-kulturowa. Analiza etnologiczna, t. 1. Poznań-Warszawa. CESLA-UAM.

Leigue Castedo, L. (1957). El Iténez Salvaje. La Paz: Ministerio de Educación. Departamento de Arqueologia, Etnografia y Folklore.

Lima, T.S. (1999). The two and its many: Reflections on perspectivism in a Tupi cosmology. Ethnos, 64(1), 107-131.

Lima, T.S. (2000). Towards an ethnographic theory of the nature/culture distinction in Juruna cosmology. Revista Brasileira de Ciências Sociais, (SPE1), 43-52.

Meireles, D.M. (1989). Guardiães da fronteira: Rio Guaporé, século XVIII. Petrópolis: Vozes.

Meireles, D.M. (1991). O complexo cultural do Marico: sociedades indígenas dos rios Branco, Colorado e Mequens, afluentes do Médio Guaporé. Boletim Do Museu Paraense Emílio Goeldi, 7(2), 209-269.

Posern-Zieliński, A. (2005). Między indygenizmem a indianizmem: andyjscy Indianie na drodze do etnorozwoju. Poznań: Wydawnictwo Naukowe UAM.

Rydén, S. (1958). Los indios Moré. Notas etnográficas. La Paz: Ministerio de Educación. Departamento de Arqueologia, Etnografia y Folklore. 
Seeger, A., Da Matta, R., Viveiros de Castro, E.B. (2019 [1979]). The construction of the person in indigenous Brazilian societies. HAU: Journal of Ethnographic Theory, 9(3), 694-703.

Snethlage, E.H. (1937). Atiko Y: meine Erlebnisse bei den Indianern des Guaporé. Berlin: Klinkhardt \& Biermann.

Snethlage, E.H. (2016). Die Guaporé-Expedition (1933-1935): Ein Forschungstagebuch. Aus dem Nachlass herausgegeben von Rotger M. Snethlage, Alhard-Mauritz Snethlage und Gleice Mere. Köln-Weimar: Böhlau Verlag.

Tylor, E.B. (1896). Cywilizacja pierwotna: badania rozwoju mitologji, filozofji, wiary, mowy, sztuki i zwyczajów: (z portretem autora). Przeł. Z.A. Kowerska. Warszawa: Wydawnictwo "Głosu".

Quinn, N. (2005). Finding culture in talk: a collection of methods. New York: Palgrave Macmillan. Vilaça, A. (2010). Strange Enemies: Indigenous Agency and Scenes of Encounters in Amazonia. Durham: Duke University Press.

Vilaça, A. (2016). Praying and preying: Christianity in indigenous Amazonia, t. 19. Berkeley: University of California Press.

Villar, D., Combès, I. (ed.) (2012). Las tierras bajas de Bolivia: miradas históricas y antropológicas. Madrid: Editorial El País.

Viveiros de Castro, E.B. (1992). From the Enemy's Point of View: Humanity and Divinity in an Amazonian Society. Chicago: University of Chicago Press.

Viveiros de Castro, E.B. (1998). Cosmological deixis and Amerindian perspectivism. Journal of the Royal Anthropological Institute, 4, 3, 469-488.

Viveiros de Castro, E.B. (2004). Perspectival Anthropology and the Method of Controlled Equivocation, Tipití, 2(1), 3-22.

Viveiros de Castro, E.B. (2011). Zeno and the Art of Anthropology of Lies, Beliefs, Paradoxes, and Other Truths. Common Knowledge, 17(1), 128-145.

Viveiros de Castro, E.B. (2012). Cosmological perspectivism in Amazonia and elsewhere. HAU: Masterclass Series, vol. 1.

Viveiros de Castro, E.B. (2015). The relative native: Essays on Indigenous conceptual worlds. Chicago: Hau Books.

\section{SUMMARY}

Making a collective body: processing fieldwork experience among the Bolivian Moré

The aim of this anthropological essay is to present the emotional and intellectual processes accompanying me over the years of field research among the Bolivian Moré, who belong to the Chapacura language family. The narrative structure is twofold: addressing both topics and issues that motivated me intellectually to do the research, and the attitudes of Moré themselves, as well as conceptual categories around which their narratives seem to focus. Some passages of this essay take a more analytical form, as I focus on the importance of unpredictable events, the context, and the transformation of field experience over time during the research process. I conclude that both sides of the fieldwork encounter face the task of getting to know the Other. Each gets to know the Other in a particular way through conceptual categories and ways of acting that result from their current way of being in the world.

Keywords: Amazonia, animism, fieldwork, ethnohistory, perspectivism 